Tabel 2.6 Panjang Bit pesan "selamat datang"

\begin{tabular}{|c|c|c|c|}
\hline Huruf & Panjang Bit & Frek & Total Bit \\
\hline A & 2 & 4 & 8 \\
\hline T & 2 & 2 & 4 \\
\hline G & 4 & 1 & 4 \\
\hline M & 4 & 1 & 4 \\
\hline L & 4 & 1 & 4 \\
\hline spasi & 4 & 1 & 4 \\
\hline S & 4 & 1 & 4 \\
\hline E & 4 & 1 & 4 \\
\hline D & 4 & 1 & 4 \\
\hline N & 4 & 1 & 4 \\
\hline \multicolumn{4}{|c|}{ Total Bit } \\
\hline
\end{tabular}

Pada kasus contoh diatas memberikan penghembatan atau pengompresan data sebanyak 112$44=68$ bit atau terjadi pengematan sebanyak $60.7 \%$.

Decoding merupakan kebalikan dari encoding. Decoding berarti menyusun kembali data dari string biner menjadi sebuah karakter kembali. Decoding dapat dilakukan dengan dua cara, yang pertama dengan menggunakan pohon Huffman dan yang kedua dengan menggunakan tabel kode Huffman.

Langkah-langkah decoding suatu biner dengan menggunakan pohon Huffman adalah sebagai berikut [6]: (1) Baca sebuah bit dari biner, (2) mulai dari akar, (3) untuk setiap bit pada langkah 1, lakukan traversal pada cabang yang bersesuaian, (4) ulangi langkah 1, 2 dan 3 sampai bertemu daun, (5) kodekan rangkaian bit yang telah dibaca dengan karakter di daun, dan (6) ulangi dari langkah 1 sampai semua bit di dalam string habis.

Sebagai contoh kita akan men-decoding string biner yang bernilai "1111"

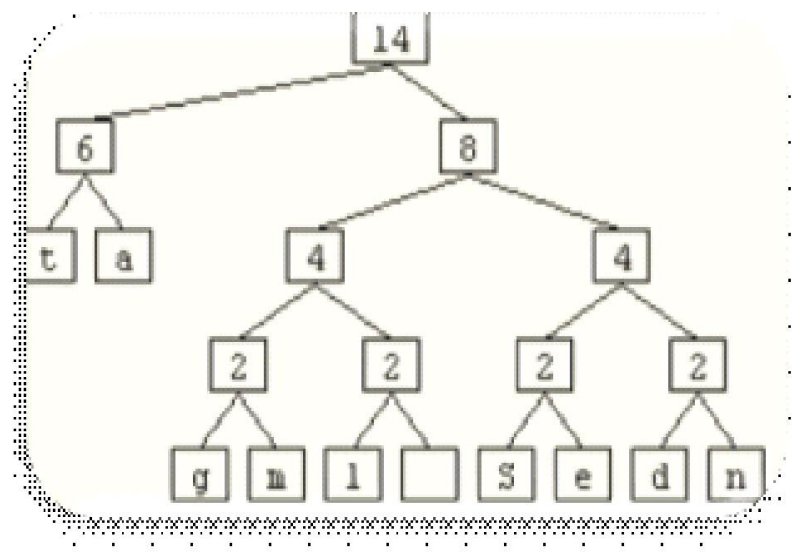

Gambar 2.3 Proses Decoding dengan Menggunakan Pohon Huffman

Dengan menelusuri dari akar, maka akan menemukan bahwa string yang mempunyai kode Huffman "1111" adalah karakter " $n$ ". selanjutnya kode Huffman "1110" adalah karakter "d" dan seterusnya.

Cara yang kedua adalah dengan menggunakan tabel kode Huffman. Sebagai contoh kita akan menggunakan kode Huffman pada Tabel 2.5 untuk merepresentasikan string "selamat datang". Dengan menggunakan Tabel 5 selanjutnya akan didecoding dengan coding secara unik. Karena tiap kode Huffman yang dihasilkan unik, maka proses decoding dapat dilakukan dengan mudah. Contoh: saat membaca kode bit pertama dalam rangkaian bit “11001101101010010110111110010011111000",

Pada kode Huffman ini, dapat dibaca mulai dari kiri. yaitu bit "1","11"."110" tidak ada dalam tabel diatas maka dapat diterjemahkan langsung kode "1100" menjadi huruf "s", selanjutnya juga kode $1,11,110$ juga tida ada maka langsung dengan kode 1101 adalah terjemahan dengan huruf "e" sehingga pada akhirnya diperoleh pesan "selamat datang"

\section{KESIMPULAN DAN SARAN \\ 3.1 Kesimpulan}

Pada akhir tulisan ini dapat disimpulkan bahwa :

1. Algoritma Huffman dapat memperkecil ukuran bit setiap karakter dalam system komputer.

2. Algoritma Huffman digunakan untuk memadatkan data dengan memanfaatkan graf pohon.

3. Graf pohon dapat diimplentasikan dalam sistem bilangan biner untuk merepresentasikan karakater computer.

\subsection{Saran}

Pada tulisan ini belum dilakukan penelitian terhadap besarnya ukuran penghematan pemadatan data yang dilakukan dengan mengunakan algoritma Huffman, sehingga diharapkan adanya penelitian lebih lanjut tentang hubungan ukuran penghematan data dengan pemilihan graf pohon pada algoritma Huffman.

\section{DAFTAR PUSTAKA}

[1] Sejarah Graf, http://repository.usu.ac.id/bitstream/ 123456789/17721/3/Chapter\%20II.pdf, akses 30 Juli 2011 22:15

[2] Yuni Dwi Astuti, Graf pohon, http:// yuni dwi.staff.gunadarma.ac.id/ Downloads/ files/12673/Bab+3++ Pohon+(Tree).pdf, akses30 Juli 2011, 22:12

[3] Minimum Spanning Tree, http://informatikauad.files.wordpress.com/2010/ 04/minimum-spanning-tree.doc

[4] Munir Rinaldi, (2001) Matematika Diskrit, Informatika Bandung.

[5] "Dasar dari Komputer, Sistem Bilangan" http://www.eazynet.net/materikuliah/ ManajemanInstalasiKomputer/ BilanganBiner2.doc waktu akses: 7 Maret 2011 23:12

[6] kompresi teks dengan menggunakan algoritma Huffman,

http://nickysuryo.files.wordpress.com/2010/03/ nickysuryoprayogo 50405515_4ia12.doc waktu akses: 7 Maret 2011 23:22

[7] Eka Aditya P.W., Kompresi Data dengan Kode Huffman dan Variasinya, http:// webmail.informatika.org/ rinaldi/Matdis/ Makalah0809-080.pdf, Waktu akses : 6 Juli 2010

[8] Sulistyohati Aprilia, Kompresi Data, http:// efrylia.files.wordpress.com/2009/10/kompresidata.pdf, waktu akses 4 Juli $2010: 23: 10$

[9] "Huffman coding", Wikipedia: http://en.wikipedia.org/ wiki/Huffman coding waktu akses: 6 Juli 2010 
J. Pijar MIPA, Vol. VI No.1, Maret : 29 - 34

ISSN 1907-1744

\title{
MODEL PERAGA SEBAGAI MEDIA PEMBELAJARAN PADA MATA PELAJARAN SAINS DAN MATEMATIKA DI SEKOLAH MENENGAH PERTAMA
}

\author{
Hikmawati'), Syahrul Azmi' \\ ${ }^{1)}$ Program Studi Pendidikan Fisika PMIPA FKIP Universitas Mataram \\ ${ }^{2)}$ Program Studi Pendidikan Matematika PMIPA FKIP Universitas Mataram \\ (hikmawati.fisika@yahoo.com)
}

\begin{abstract}
Abstrak : Salah satu tujuan pembelajaran sains dan matematika di sekolah menengah pertama adalah untuk meningkatkan pengetahuan, konsep, dan keterampilan sains dan matematika siswa sebagai dasar untuk melanjutkan pendidikan ke jenjang selanjutnya. Keberadaan media dalam pembelajaran sangat diperlukan mengingat sains dan matematika memiliki konsep-konsep abstrak yang seringkali menjadi alasan sulitnya mempelajari materi kedua mata pelajaran tersebut. Media tiga dimensi dalam sains maupun alat peraga dalam matematika merupakan model peraga yang dapat dijadikan media dalam pembelajaran. Media tiga dimensi dapat berupa gambar yang setidaknya memiliki tiga sisi (depan, belakang dan samping) sehingga sebuah gambar tiga dimensi dapat dilihat dari berbagai arah. Peranan alat peraga dalam matematika adalah meletakkan ide-ide dasar konsep sehingga dengan bantuan alat peraga yang sesuai, siswa dapat memahami ide-ide dasar yang melandasi sebuah konsep, mengetahui cara membuktikan suatu rumus atau teorema, dan dapat menarik suatu kesimpulan dari hasil pengamatannya. Dengan demikian, model peraga dapat digunakan sebagai alat peraga untuk menerangkan konsep materi pelajaran sehingga siswa menjadi lebih tertarik, berminat dan memiliki motivasi belajar yang pada akhirnya akan meningkatkan prestasi belajar siswa.
\end{abstract}

Kata-kata kunci : model peraga, media pembelajaran.

\begin{abstract}
One goal of learning science and mathematics in secondary schools is to improve the knowledge, concepts, and skills of science and mathematics students as a basis for continuing their education to the next. The presence of media in learning is necessary considering the science and mathematics have the abstract concepts that are often the reason for the difficulty of studying the material both these subjects. Three-dimensional media in science and mathematics teaching aids in a visual model that can be used as media of learning. Media can be either three-dimensional image that has at least three sides (front, rear and side) so that a three-dimensional images can be viewed from various directions. The role of teaching aids in mathematics is to put the basic ideas of the concept that with the aid of appropriate props, students can grasp the basic ideas underlying the concept, knowing how to prove a formula or theorem, and can draw a conclusion from the results of his observations. Thus, the model can be used as a visual prop to explain the concept of subject matter so that students become more interested, interested and motivated to learn, which in turn will improve student achievement.
\end{abstract}

Key words : models of visual aids, learning media.

\section{PENDAHULUAN}

Salah satu tujuan pembelajaran sains dan matematika di sekolah menengah pertama adalah untuk meningkatkan pengetahuan, konsep, dan keterampilan sains dan matematika siswa sebagai dasar untuk melanjutkan pendidikan ke jenjang selanjutnya.

Pendidikan sains menekankan pada pemberian pengalaman langsung untuk mengembangkan kompetensi agar siswa mampu menjelajahi dan memahami alam sekitar secara ilmiah. Pendidikan matematika diharapkan sebagai dorongan untuk memiliki pandangan yang cukup luas dan memiliki sifat logis, kritis, cermat, dan disiplin serta menghargai kegunaan matematika.

Dalam [1] dikatakan bahwa berdasarkan norma usia yang dikemukan oleh Piaget, siswa sekolah menengah pertama dengan rentangan usia 14-17 tahun mengalami tahap transisi dari penggunaan operasi kongkrit ke penerapan operasi formal dalam bernalar. Hal ini dapat menyebabkan sulitnya materi IPA/ilmu sains (biologi dan fisika) dipahami oleh siswa dan juga sifat-sifat ilmu sains yang abstrak dan perhitungan matematik sehingga menjadikan ilmu sains sebagai salah satu mata pelajaran yang dianggap sulit oleh siswa menengah pertama. Demikian pula halnya dengan mata pelajaran matematika.

Untuk itu diperlukan keberadaan media dalam pembelajaran. Dengan adanya media siswa akan merasa lebih tertarik dan berminat dalam belajar. Media yang dirancang dengan baik dapat merangsang timbulnya interaksi dalam diri siswa, dengan kata lain terjadi komunikasi antara siswa dengan media atau secara tidak langsung antara siswa dengan sumbernya pesan yaitu guru. Bila terjadi demikian maka dapat dikatakan bahwa proses kegiatan belajar telah terjadi. Media berhasil membawa pesan belajar bila terjadi perubahan tingkah laku atau sikap belajar pada diri siswa.

Dalam mengefektifkan proses pembelajaran, seorang guru harus mampu memilih metode yag tepat agar tujuan pembelajaran dapat tercapai. Berdasarkan hasil penelitian dibidang psikologi seperti yang dilaporkan Dikdas Depdiknas dalam [2] menunjukkkan bahwa hasil belajar adalah $1 \%$ dari indera perasa, $1,5 \%$ dari indera peraba, $3,5 \%$ dari indera penciuman, $11 \%$ dari indera pendengaran, dan $83 \%$ dari indera penglihatan (sight). Lebih lanjut dikatakan bahwa perpaduan antara aspek verbal dan visual dalam proses belajar mengajar 
memungkinkan seseorang memiliki kemampuan mengingat yang tinggi. Hubungannya dengan peningkatan mutu pendidikan, penggunaan media mutlak diterapkan oleh guru dan pengelola pendidikan lainnya untuk mencapai hasil terbaik yang optimal dari segi afektif, kognitif dan psikomotor.

Salah satu media pembelajaran yang penulis maksudkan adalah model peraga, dimana model peraga ini digunakan sebagai alat peraga untuk menerangkan ideide/konsep-konsep materi pelajaran sehingga siswa menjadi lebih tertarik, berminat dan memiliki motivasi belajar yang pada akhirnya akan meningkatkan prestasi belajar siswa.

Bagian selanjutnya dalam tulisan ini akan membahas tentang peran media, macam-macam media, penggunaan media dalam pembelajaran, dan media tiga dimensi sebagai model peraga dalam pembelajaran sains (fisika), serta model peraga prisma sebagai model peraga dalam pembelajaran matematika.

\section{PEMBAHASAN}

\subsection{Peran Media Dalam Pembelajaran}

Pada mulanya media hanya berfungsi sebagai alat bantu visual dalam kegiatan belajar/mengajar, yaitu berupa sarana yang dapat memberikan pengalaman visual kepada siswa antara lain utuk mendorong motivasi belajar, memperjelas dan mempermudah konsep yang abstrak dan mempertinggi daya serap atau retensi belajar. Kemudian dengan masuknya pengaruh teknologi audio pada sekitar pertengahan abad 20 lahirlah peraga audio-visual yang terutama menekankan penggunaan pengalaman yang konkrit untuk menghindarkan verbalisme.

Komponen penting dalam sistem komunikasi, antara lain pengiriman pesan, pesan, saluran dan penerima. Pada komunikasi dalam proses belajar-mengajar, guru menjadi sumber dan komunikator, siswa menjadi komunikan dan menjadi tujuan pesan. Agar pesan dapat sampai ke tujuan dengan efektif dan efisien harus digunakan media. Dalam pendidikan, media tersebut dinamakan media pendidikan atau media instruksional. Dalam penggunaan media, pesan dapat dinyatakan dalam bentuk simbol piktoral, simbol grafis, dan simbol verbal. Dengan menggunakan media pendidikan, dapat ditanggulangi berbagai kelemahan dalam sistem komunikasi.

Media pendidikan disebut juga media instruksional, yang memiliki nilai praktis dan berfungsi mengatasi perbedaan pengalaman pribadi murid, mengatasi batas-batas ruang kelas, keterbatasan karena jarak, waktu dan mengatasi hal-hal yang terlalu komplek untuk diamati. Sebelum membuat suatu media pendidikan dalam pembelajaran di sekolah, guru hedaknya merancang pesan yang sangat erat kaitannya dengan media instruksional.

Menurut Maya dalam [3] sebagai bagian dari sistem pembelajaran, media mempunyai fungsi atau peranan sebagai berikut:

a) Membuat konkrit konsep yang abstrak, misalnya untuk menjelaskan system peredaran darah. b) Membawa obyek yang berbahaya atau sukar didapat ke dalam lingkungan belajar seperti binatang-binatang buas atau penguin dari kutub selatan.

c) Menampilkan obyek yang terlalu besar misalnya pasar, candi Borobudur dan sebagainya.

d) Menampilkan obyek yang tak dapat diamati dengan mata telanjang seperti mikroorganisme.

e) Mengamati gerakan yang terlalu cepat misalnya dengan slowmotion atau time-lapse photography.

f) Memungkinkan siswa berinteraksi langsung dengan lingkungannya.

g) Memungkinkan keseragaman pengamatan dan persepsi bagi pengalaman belajar siswa.

h) Membangkitkan motivasi belajar.

i) Memberi kesan perhatian individual untuk seluruh anggota kelompok belajar.

j) Menyajikan informasi belajar secara konsisten dan dapat diulang maupun disimpan menurut kebutuhan.

k) Menyajikan pesan atau informasi belajar secara serempak, mengatasi batasan waktu maupun ruang.

1) Mengontrol arah maupun kecepatan belajar siswa.

Depdiknas dalam [3] mengidentifikasi beberapa fungsi media pembelajaran lainya, yaitu sebagai berikut:

1. Penyampaian materi pelajaran dapat diseragamkan.

2. Proses pembelajaran menjadi lebih interaktif.

3. Efisien dalam waktu dan tenaga.

4. Meningkatkan kualitas hasil belajar siswa.

5. Media memungkinkan proses belajar dapat dilakukan dimana saja dan kapan saja.

6. Proses pembelajaran menjadi lebih jelas dan menarik.

7. Media dapat menumbuhkan sikap positif siswa terhadap materi dan proses belajar.

8. Merubah peran guru ke arah yang lebih positif dan produktif.

Pengenalan tentang fungsi dan kemampuan media ini sangat penting artinya bila media akan merupakan bagian integral dari sistem pembelajaran karena dasar kebijakan dalam pemilihan, pengembangan, maupun pemamfaatan media tidak dapat terlepas dari pengetahuan ini.

\subsection{Macam-Macam Media Dalam Pembelajaran}

Media dalam pembelajaran (fisika maupun matematika) dapat berupa media cetak, media pajang, media peraga, media eksperimen, OHP, OHP dan kombinasinya, slide, film strip, film, VCD, TV instruksional, internet, dan sebagainya. Menurut Wilbur Schramm dalam [4], media pembelajaran dibedakan menjadi dua macam, yaitu media besar dan media kecil. Media besar diartikan sebagai media yang kompleks dan mahal, seperti TV, Film, Komputer, dan sejenisnya. Media nonelektronik yang sering digunakan dalam pembelajaran Fisika, dapat meliputi: media cetak, media pajang, media peraga, media eksperimen. Selanjutnya untuk media elektronik dalam pembelajaran Fisika, dapat berupa: OHP, OHP dan kombinasinya, program slide instruksional, program film strip, film instruksional, VCD, TV instruksional dan internet. 
Ada berbagai macam bentuk dan jenis media pembelajaran yang secara khusus sengaja dirancang untuk keperluan pembelajaran. Sudjana dalam [3] memaparkan beberapa media pengajaran yang bisa digunakan dalam proses pengajaran, antara lain:

1. Media Grafis (media dua dimensi) seperti gambar, foto, grafik dan bagan atau diagram, poster, kartun, komik dan lain-lain.

2. Media Tiga Dimensi yaitu dalam bentuk bentuk model seperti model padat (solid model), model penampang, model susun, model kerja dan lain-lain.

3. Media Proyeksi, seperti seperti slide, film strips, film, penggunaan OHP dan lain-lain.

4. Penggunaan lingkungan sebagai media pengajaran.

Bahri dalam [3], mengelompokkan media berdasarkan jenis, daya liput, bahan serta cara pembuatannya sebagai berikut :

1. Di lihat dari jenisnya, media dibagi ke dalam :

\section{a. Media Auditif}

Media auditif adalah media yang hanya mengandalkan kemampuan suara saja, seperti radio, cassette recorder, piringan hitam. Media ini tidak cocok untuk orang tuli atau mempunyai kelainan dalam pendengaran

\section{b. Media Visual}

Media visual adalah media yang hanya mengandalkan indra pengelihatan. Media visual ini ada yang menampilkan gambar diam seperti film strip (film rangkai), slides (film bingkai) foto, gambar atau lukisan, cetakan. Ada pula media visual yang menampilkan gambar atau simbol yang bergerak seperti film bisu, film kartun.

\section{c. Media Audiovisual}

Media audiovisual adalah media yang mempunyai unsur suara dan unsur gambar. Jenis media ini mempunyai kemampuan yang lebih baik, karena meliputi kedua jenis media yang pertama dan kedua. Media ini dibagi lagi ke dalam:

1) Audiovisual Diam, yaitu media yang menampilkan suara dan gambar diam seperti film bingkai suara (sound slides), film rangkai suara, cetak suara.

2) Audiovisual Gerak, yaitu media yang dapat menampilkan unsur suara dan gambar yang bergerak seperti film suara dan video-cassette. Pembagian lain dari media ini adalah:

a) Audiovisual Murni yaitu baik unsur suara maupun gambar berasal dari suatu sumber seperti filem video-cassette, dan

b) Audiovisual Tidak Murni yaitu yang unsur suara dan gambarnya berasal dari sumber yang berbeda, misalnya film bingkai suara yang unsur gambarnya bersumber dari slides proyektor dan unsur suaranya bersumber dari tipe recoder. Contoh lainnya adalah film strip suara dan cetak suara.

2. Dilihat dari dari daya liputannya, media dibagi dalam: a. Media dengan daya liputan luas dan serentak

Penggunaan media ini tidak terbatas oleh tempat dan ruang serta dapat menjangkau jumlah anak didik yang banyak dalam waktu yang sama, contohnya : radio dan televisi.

b. Media dengan daya liput yang terbatas oleh ruang dan tempat
Media ini dalam penggunaannya membutuhkan ruang dan tempat yang khusus seperti film, sound slide, film rangkai yang harus menggunakan tempat yang tertutup dan gelap.

\section{c. Media untuk pengajaran individual}

Media ini penggunaannya hanya untuk seorang diri termasuk media ini adalah modul berprogram dan pengajaran melalui komputer.

3. Dilihat dari bahan pembuatannya, media dibagi dalam:

\section{a. Media Sederhana}

Media ini bahan dasarnya mudah diperoleh dan harganya murah, cara pembuatannya mudah dan penggunaannya tidak sulit.

\section{b. Media Kompleks}

Media ini adalah media yang bahan dan alat pembuatannya sulit diperoleh serta mahal harganya, sulit membuatnya dan penggunaannya memerlukan keterampilan yang memadai.

\subsection{Penggunaan Media Dalam Pembelajaran}

Penggunaan media pengajaran kurang tepat jika dinilai dari segi kecanggihan medianya saja, tetapi yang paling penting adalah fungsi dan peranannya dalam membantu mempertinggi proses pengajaran. Oleh sebeb itu penggunaan media pengajaran sangat bergantung kepada tujuan pengajaran, bahan pengajaran, kemudahan memperoleh media yang diperlukan, serta kemampuan guru dalam menggunakannya dalam proses pengajaran.

Menurut Sudjana dalam [3] terdapat beberapa kriteria yang harus diperhatikan dalam memilih media untuk kepentingan pengajaran antara lain sebagai berikut:

a. Ketepatannya dengan tujuan pengajaran:artinya media pengajaran dipilih atas dasar tujuan-tujuan instruksional yang telah ditetapkan.

b. Dukungan terhadap isi bahan pelajaran:artinya bahan pelajaran yang sifatnya fakta, prinsip, konsep dan generalisasi sangat memerlukan bantuan media agar lebih mudah dipahami siswa.

c. Kemudahan memperoleh media dan setidak-tidaknya bisa dibuat oleh guru tanpa biaya yang mahal.

d. Keterampilan guru dalam menggunakannya pada proses pembelajaran

e. Tersedia waktu untuk menggunakannya: sehingga media tersebut dapat bermamfaat bagi siswa selama pengajaran berlangsung.

f. Sesuai dengan taraf berfikir siswa sehingga makna yang terkandung didalamnya dapat dipahami dengan mudah oleh

\subsection{Model Peraga}

Media tiga dimensi merupakan salah satu media yang dapat digunakan dalam pembelajaran sains (fisika) di sekolah menengah pertama, dan model peraga prisma merupakan salah satu media yang dapat digunakan dalam pembelajaran matematika.

\section{Media Tiga Dimensi}

Seperti halnya pelajaran matematika, fisika sebagai cabang ilmu sains yang memiliki konsep abstrak sering menjadi kendala bagi anak-anak untuk 
mempelajarinya. Bayangan rumitnya teori yang diajarkan dan perhitungan yang bisa membuat mata pelajaran fisika menjadi pilihan sedikit anak. Hanya anak-anak dengan tingkat kepandaian tertentu saja yang mampu menyerap berbagai teori yang diajarkan oleh para guru di kelas. Salah satu media pembelajaran yang dapat digunakan dalam pembelajaran adalah media tiga dimensi, yaitu gambar yaang setidaknya memiliki tiga sisi (depan, belakang dan samping). Dengan demikian sebuah gambar tiga dimensi dapat dilihat dari berbagai arah.

Keberadaan media tiga dimensi akan besar pengaruhnya bagi siswa dalam mencapai kompetensi pembelajaran yang telah ditetapkan. Alat, bahan dan proses pembuatan gambar dapat dilakukan dengan membuat gambar sendiri atau menggunting dari gambar foto, poster, buku atau media cetak lain atau memanfaatkan barangbarang bekas.

Alat-alat peraga bisa di buat sangat sederhana dan menarik sama dengan alat-alat peraga buatan pabrik walaupun sedikit ada perbedaan. Hal ini bertujuan agar siswa juga dapat membuat dan mencoba sendiri di rumah atau sebagai tugas sekolah untuk materi fisika yang lain atau mata pelajaran yang lain. Berikut contoh model peraga (alat peraga) sains untuk menjelaskan konsep peristiwa Kapilaritas.

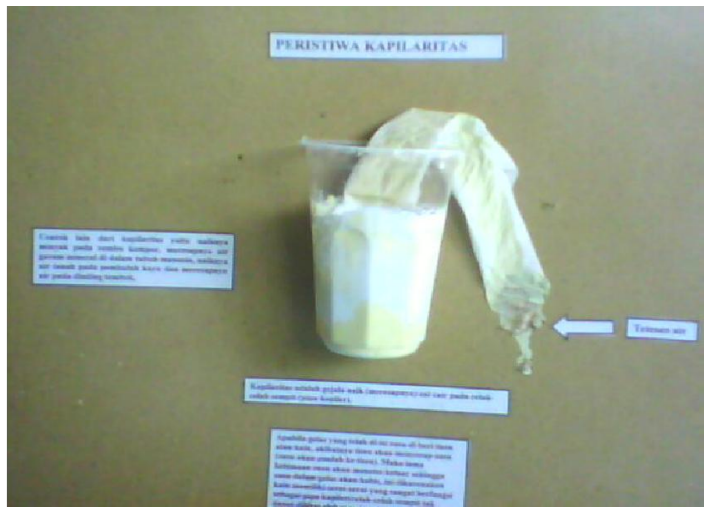

(Sumber: Pendawati, 2010)

Media pembelajaran tiga dimensi di atas didesain dengan menggunakan alat dan bahan sederhana yang terbuat dari kertas karton tebal, cat air, lem kertas, dan plastik-pastik bekas minuman. Alat peraga tersebut dapat dilihat dari sisi depan, samping dan belakang. Alat peraga tiga dimensi selanjutnya ditempelkan pada kertas karton tebal yang bisa dipajang di dinding kelas sebagai model peraga untuk peristiwa kapilaritas.

Kapilaritas adalah gejala naik (meresapnya) zat cair pada celah-celah sempit (pipa kapiler). Kegiatan pembelajaran untuk mengamati peristiwa kapilaritas pada tissu membutuhkan alat dan bahan yaitu: air, tissu, dan gelas. Adapun prosedur kerja yang dapat dilakukan siswa adalah sebagai berikut: (1) Isilah gelas dengan air; (2) Masukkan sebagian tissu kering ke dalam gelas seperti pada gambar!; (3) Tunggulah sampai beberapa saat!

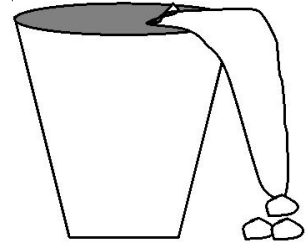

(Sumber: Pendawati, 2010)

Guru bisa memberikan beberapa pertanyaan kepada siswa, antara lain: (1) Mengapa semua tissu menjadi basah?; (2) Apa sebabnya?

Menurut Ahmad [5], dalam pembuatan media pembelajaran selain dapat menekan biaya ekonomis juga dalam pembuatannya dapat melibatkan peran serta siswa, bahkan dapat menciptakan suasana kompetitif dalam pembuatannya, sehingga tercipta suasana kompetitif. Manfaat lain yang akan di peroleh adalah siswa lebih menguasai kompetensi pembelajaran yang harus dicapai karena disini terjadi proses pembelajaran kontekstual.

Menurut [6] mengidentifikasi beberapa fungsi media pembelajaran lainya, yaitu sebagai berikut: (1) Penyampaian materi pelajaran dapat diseragamkan; (2) Proses pembelajaran menjadi lebih interaktif; (3) Efisien dalam waktu dan tenaga; (4) Meningkatkan kualitas hasil belajar siswa; (5) Media memungkinkan proses belajar dapat dilakukan dimana saja dan kapan saja; (6) Proses pembelajaran menjadi lebih jelas dan menarik; (7) Media dapat menumbuhkan sikap positif siswa terhadap materi dan proses belajar; (8) Merubah peran guru ke arah yang lebih positif dan produktif.

Brunner mengatakan bahwa dalam proses belajar mengajar siswa sebaiknya diberi kesempatan untuk memanipulasi benda-benda nyata (berupa alat peraga). Penelitian yang dilakukan oleh Higgins dan Suydam memberikan hasil-hasil berikut: (1) Secara umum hasil penelitian yang dilaksanakan tersebut mengisyaratkan bahwa alat peraga berfungsi efektif dalam memotivasi belajar siswa; (2) Terdapat perbandingan keberhasilan 6 : 1 antara pengajaran yang menggunakan alat peraga dengan yang tidak menggunakan; (3) Memanipulasi (mengutakatik) alat peraga sangat penting bagi siswa; (4) Terdapat sedikit bukti yang menggambarkan bahwa memanipulasi alat peraga hanya berhasil bagi siswa dengan tingkat kemampuan rendah; (5) Gambar dari benda, sebagai alat peraga dalam pengajaran, memiliki kegunaan yang tidak jauh berbeda dengan bendanya sendiri. Penelitian penggunaan alat peraga yang dilakukan oleh Higgins dan Susi tahun 1976 dalam [7] menemukan bahwa sekitar 90 $\%$ keberhasilan yang meyakinkan dari belajar adalah karena penggunaan alat peraga.

Dengan model peraga, siswa dapat melihat langsung bagaimana keteraturan pola yang terdapat pada benda yang sedang diamati.

Penggunaan alat peraga harus dilaksanakan secara cermat, jangan sampai konsep menjadi lebih rumit akibat diuraikan dengan bantuan alat peraga. Penggunaan alat peraga harus mampu menghasilkan generalisasi atau kesimpulan abstrak dari representasi konkret. Alat peraga yang digunakan tanpa persiapan bisa mengakibatkan habisnya waktu dan sedikitnya materi yang dapat 
disampaikan. Jika hal ini terjadi, maka dapat dikatakan bahwa alat peraga yang kita pakai atau cara penggunaan alat peraga yang kita gunakan tidak mencapai sasaran.

\section{Model Peraga Prisma}

Dalam pelajaran matematika, pemahaman konsep atau masalah adalah sangat penting dalam menyelesaikan masalah tersebut. Menurut George Polya dalam [7] menerangkan bahwa langkah-langkah menyelesaikan masalah sebagai berikut: (1) Memahami masalah; (2) Merencanakan penyelesaian masalah; (3) Melaksanakan penyelesaian masalah; (4) Menguji kebenaran hasil. Berdasarkan pendapat tersebut bahwa dalam penyelesaian masalah matematika yang menjadi dasar utamanya adalah memahami konsep atau paham terhadap masalah tersebut.

Dari Bloom, dkk. sebagaimana yang dikutip [7] menyatakan bahwa jenjang pemahaman terdiri dari pemahaman konsep, pemahaman prinsip, aturan dan generalisasi, pemahaman terhadap struktur matematika, kemampuan untuk membuat transformasi, kemampuan untuk mengikuti pola fikir, kemampuan untuk membaca dan menginterpretasikan masalah sosial atau data matematika.

Banyak sekali upaya yang dapat dilakukan guru dalam menciptakan proses belajar mengajar yang efektif dan efisien untuk mencapai tujuan pembelajaran, salah satunya adalah dengan penggunaan alat bantu mengajar berupa alat peraga. Model peraga yang digunakan dalam menjabarkan rumus luas permukaan bangun ruang dapat menarik minat dan motivasi siswa dalam belajar, karena siswa menjadi mengerti darimana rumus luas sisi (permukaan) bangun ruang terbentuk, sehingga siswa berusaha mencari sendiri luas sisi bangun ruang yang lain, yang pada akhirnya konsep akan tertanam lebih kuat dalam diri siswa. Dengan menggunakan alat peraga akan membantu memperjelas konsep tahap demi tahap, memberikan gambaran konkret ide-ide yang abstrak. Alat peraga membantu kejelasan bukti teorema-teorema secara logis dan urutan pembuktiannya sesuai dengan perkembangan mental siswa.

Menurut [8] memberikan definisi bahwa alat peraga adalah alat, metode, teknik yang digunakan dalam rangka mengefektifkan komunikasi dan interaksi antara guru dan siswa dalam proses pendidikan dan pembelajaran di sekolah. Dalam arti umum, alat peraga adalah semua bentuk perantara yang dipakai orang sebagai penyalur ide, sehingga ide (gagasan) sampai pada penerima. Menurut [9] salah satu peranan alat peraga dalam matematika adalah meletakkan ide-ide dasar konsep. Dengan bantuan alat peraga yang sesuai, siswa dapat memahami ide-ide dasar yang melandasi sebuah konsep, mengetahui cara membuktikan suatu rumus atau teorema, dan dapat menarik suatu kesimpulan dari hasil pengamatannya.

Untuk memahami konsep luas permukaan bangun ruang tentunya siswa harus memahami hubungan antara garis dengan garis, garis dengan bidang, bidang dengan bidang dalam suatu bangun ruang. Prisma merupakan bentuk bangun ruang. Bangun ruang adalah suatu materi pokok dalam pelajaran matematika yang mempelajari bentuk, letak, ukuran dan sifat-sifat suatu bangun yang tidak terletak pada satu bidang datar. Prisma merupakan gabungan dari beberapa buah bangun datar yang dibentuk menjadi sebuah bangun ruang.

Prisma adalah bangun ruang yang dibatasi oleh dua sisi berhadapan yang kongruen dan sejajar, serta sisisisi lain yang berpotongan menurut rusuk-rusuk yang sejajar [10].

Langkah-langkah dalam menemukan rumus luas permukaan bangun ruang (prisma) dengan menggunakan model peraga adalah sebagai berikut.

a). Sebuah bangun ruang, misalnya prisma tegak segitiga beraturan ABC.DEF, panjang rusuk tegaknya (tinggi prisma) adalah $\mathrm{p}$ dan panjang rusuk bidang alas prisma masing-masing $1_{1}, 1_{2}$, dan $1_{3}$.

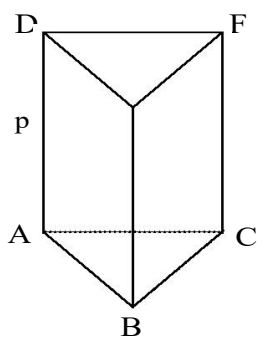

b). Kemudian rusuk tegaknya $\overline{B E}$ diiris, kemudian mengiris rusuk-rusuk bidang alas yaitu $\overline{B C}$ dan $\overline{A B}$, kemudian mengiris bidang atas yaitu $\overline{E D}$ dan $\overline{E F}$.

c). Setelah rusuk-rusuk tersebut kita iris, kemudian direbahkan pada sebuah bidang datar. Dari sini akan jelas terlihat bidang-bidang yang menyusun bangun prisma tersebut, yaitu berupa dua bidang segitiga yang kongruen dan tiga bidang persegi panjang, terlihat seperti gambar dibawah:

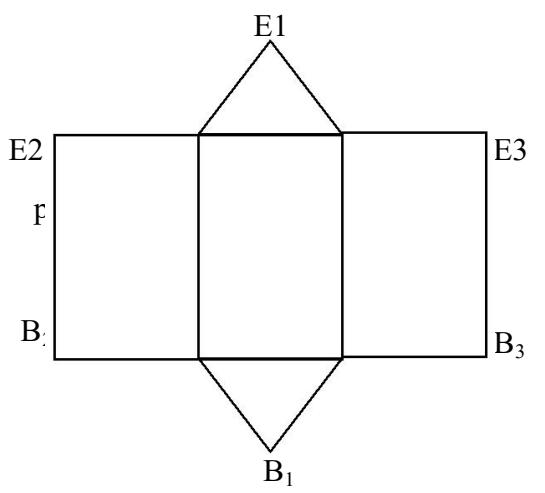

d). Mencari luas dari masing-masing bidang penyusun bangun prisma tersebut.

e). Setelah mendapatkan luas dari masing-masing bidang penyusun tersebut, luas seluruh bidang penyusun tersebut dijumlahkan yaitu luas bidang I + luas bidang $I I+$ luas bidang III + luas bidang $I V+$ luas bidang $V$, hasil penjumlahan tersebut merupakan luas dari sisi (permukaan) bangun prisma, yaitu: luas prisma $=2$ luas alas + (keliling alas $x$ tinggi).

\section{KESIMPULAN}

Dari pembahasan di atas dapat diambil beberapa kesimpulan sebagai berikut.

1. Peran media dalam pembelajaran antara lain adalah untuk membuat konkrit konsep yang abstrak, membawa obyek yang berbahaya atau sukar didapat 